\title{
Producción y calidad de forraje de variedades de avena en condiciones de temporal en Zacatecas, México
}

\section{Yield and forage quality of oats varieties under rainfed conditions in Zacatecas, Mexico}

\author{
Ricardo A. Sánchez Gutiérreza, Héctor Gutiérrez Bañuelos ${ }^{b}$, Alfonso Serna Péreza \\ Ramón Gutiérrez Lunaa, Alejandro Espinoza Canalesb
}

\begin{abstract}
RESUMEN
Se evaluó la producción, calidad y componentes de rendimiento de seis variedades de avena forrajera en Zacatecas. Los experimentos se establecieron en julio de 2011 y 2012 en el municipio de Monte Escobedo. El diseño experimental fue bloques completos al azar con tres repeticiones, la densidad de siembra fue $120 \mathrm{~kg} \mathrm{ha}^{-1}$ y dosis de fertilización de 60-40-00 de $\mathrm{N}, \mathrm{P}_{2} \mathrm{O}_{5}, \mathrm{~K}$. La cosecha fue en estado fisiológico lechoso-masoso. En 2011 y 2012, La variedad Saía sobresalió $(\mathrm{P}<0.05)$ entre cultivares en rendimiento de forraje seco con 3.7 y 5.6 ha-1, altura de planta con 119 y $120 \mathrm{~cm}$, y en componentes de rendimiento acumuló la mayor $(\mathrm{P}<0.05)$ proporción de hoja y tallo. La variedad Karma sobresalió en proporción de espiga con 42 y $49 \%$ ( $(P<0.05)$ en 2011 y 2012, respectivamente. En proteína cruda los resultados fueron similares ( $P>0.05)$ entre variedades con un rango de 10.6 a $13.8 \%$. En los dos años de estudio Karma presentó las mejores características nutricionales: baja acumulación de fibra detergente neutro (51 \%) y acida ( 33.4 y $35.3 \%$ ), valores altos en total de nutrientes digestibles (54 y 58 \%), digestibilidad de la materia seca (60 y $62 \%)$, valor relativo del forraje (110 y 113) y energía neta para lactación (1.4 y 1.34 Mcal/ kg; P<0.05). Las variables asociadas de manera positiva con forraje seco fueron altura de planta $(r=0.701)$, días a cosecha $(r=0.685)$ y proporción de tallo $(r=0.629)$, y negativamente con proporción de espiga $(r=-0.629)$. En calidad nutricional Karma tuvo mejor valor forrajero. Saia es una buena alternativa para incrementar el rendimiento de forraje por hectárea.
\end{abstract}

PALABRAS ClaVe: Avena sativa, Perfil bromatológico, Productividad, Componentes del rendimiento.

\begin{abstract}
Yield, quality and yield components of six varieties of oat for forage were evaluated in Zacatecas. Experiments were established on J uly 2011 and 2012 at Monte Escobedo. A complete randomized block experimental design replicated three times was used. Oat seeding density was $120 \mathrm{~kg} \mathrm{ha}^{-1}$ and NPK fertilizer application rate of 60-40-00. Harvest was at milky-dough stage of maturity. In both years, 2011 and 2012, Saia stood out among cultivars (P<0.05) in forage yield with 3.7 and $5.6 \mathrm{t}$ DM ha-1, plant height with 119 and $120 \mathrm{~cm}$, and with respect to yield components accumulated the larger proportion of leaf and stem $(P<0.05)$. Karma stood out in the proportion of spike with 42 and $49 \%(P<0.05)$ in 2011 and 2012, respectively. Results of crude protein were similar $(P>0.05)$ among varieties with a range of $\mathbf{1 0 . 6}$ to $\mathbf{1 3 . 8} \%$. On two years of study Karma showed the best nutritional characteristics: low accumulation of neutral detergent fiber $(51 \%)$ and acid detergent fiber ( 33.4 and $35.3 \%$ ), high values of digestible nutrients (54 and $58 \%$ ), dry matter digestibility (60 and $62 \%)$, forage relative value (110 and 113) and lactation net energy (1.4 y $1.34 \mathrm{Mcal} / \mathrm{kg} ; \mathrm{P}<0.05)$. Dry forage yield was positively correlated to plant height $(\mathrm{r}=0.701)$, days from sowing to harvest $(r=0.685)$ and stem proportion $(r=0.629)$, and negatively correlated to spike proportion $(r=-0.629)$. In relation to the nutritional quality, Karma had the best forage value. Saia is a good alternative to increase forage yield per hectare.
\end{abstract}

KEY WORDS: Avena sativa, Dry mater yield, Nutritional quality, Yield components.

Recibido el 22 de agosto de 2013. Aceptado el 18 de octubre de 2013.

a Campo Experimental Zacatecas. INIFAP. Km. 24.5 Carretera Zacatecas-Fresnillo, 98500 Calera de V.R. Zacatecas, México. sanchez.ricardo@inifap.gob.mx. Correspondencia al primer autor.

b Facultad de Medicina Veterinaria, Universidad Autónoma de Zacatecas. México. 


\section{INTRODUCCIÓN}

La avena (Avena sativa) en México es un cultivo que tiene una amplia adaptación climática, pues llega a prosperar en zonas frías, templadas, áridas y semicálidas. De esta especie, la avena forrajera es el tercer cultivo de importancia económica. Tan sólo en el año 2011 la superficie sembrada fue mayor a 830 mil ha y más del $98 \%$ se sembró en condiciones de temporal( 1 ). En Zacatecas en los últimos 10 años la superficie dedicada a la siembra de avena ha aumentado de 96 mil hasta 180 mil ha(1). Este cultivo es una alternativa para las siembras tardías cuando ya no se recomienda el establecimiento de maíz o frijol. Medina et al(2) reportan que en el estado hay $\mathbf{4 7 0}$ mil ha con potencial para cultivar avena bajo condiciones de temporal. En temporal, las condiciones de precipitación óptimas para este cultivo son de 400 a 500 $\mathrm{mm}(3,4)$ aunque se puede cultivar en regiones donde la precipitación acumulada llega a ser de 250 a $770 \mathrm{~mm}$. En estos lugares, su forraje representa una opción para la ganadería, ya que sirve para la suplementación de becerros en invierno y mantenimiento del ganado durante la época de sequía $(5,6)$.

Investigaciones han mostrado que en la avena existen contrastes de la máxima producción de forraje y la alta calidad nutritiva, esto se debe al estado de madurez en la que se encuentra la planta. Si la intención del productor es obtener un alto contenido de proteína y niveles bajos de fibra, el momento óptimo del corte es en estado vegetativo. Mientras que en las cosechas en estado de grano avanzado, se han obtenido los mayores rendimientos de forraje pero con cantidades bajas de proteína $(7,8)$. Lo anterior está muy ligado a las fracciones morfológicas de la avena; en estado vegetativo la acumulación de hojas es alta, conforme empieza a crecer la planta el porcentaje de hojas disminuye, y el de tallo aumenta. Un estado óptimo para maximizar los rendimientos por hectárea, es en la etapa de lechoso-masoso a masoso-suave $(9,10,11)$. Cuando el corte se realiza en esta etapa, las características

\section{INTRODUCTION}

Oats (Avena sativa) in Mexico is a crop with a broad climate adaptation, because it comes to thrive in cold, temperate, arid, and semi-arid areas. From this species, forage oats is the third crop of economic importance. J ust in 2011 the planted area was higher than 830,000 ha and more than $98 \%$ was harvest under rainfed conditions(1). In Zacatecas in the last $10 \mathrm{yr}$ the area dedicated to oats sowing increased from 96,000 to $180,000 \mathrm{ha}(1)$. This crop is an altemative for late sowings, when the establishment of maize or bean is no longer recommended. Medina et al(2) reported that in the State there are 470,000 ha potential for oats cropping under rainfed conditions. Optimal Rainfall precipitation for this crop are 400 to $500 \mathrm{~mm}^{(3.4)}$ although it can be cultivated in regions where the accumulated precipitation becomes 250 to 770 $\mathrm{mm}$. In these areas, their forage represents an option for livestock, because it serves for calves supplementation in winter and livestock maintenance during the drought $(5,6)$.

Research has shown that there are contrasts of high forage production and nutritional quality in oats, due to the stage of plant maturity. If the producer intention is to obtain a high content of protein and low levels of fiber, the optimal timing is cut in a vegetative state. While harvests in advanced state of grain, achieve the highest forage yields but with low amounts of protein $(7,8)$. This is closely linked to the morphological oats fractions; accumulation of leaves in a vegetative state is high, as the plant begins to grow decreases the percentage of leaves and the stem increases. Optimum condition for maximizing yields per hectare, is at the stage of milky-dough to doughsoft $(9,10,11)$. When the cut is made at this stage, the nutritional characteristics of forage, such as in vitro digestibility, net energy for lactation and neutral detergent fiber digestibility, are considered of good quality(12).

One of the main criteria in the selection of any oat variety is the biomass composition, it has 
PRODUCCIÓN DE FORRAJE DE VARIEDADES DE AVENA EN CONDICIONES DE TEMPORAL

nutricionales del forraje, como digestibilidad in vitro, energía neta de lactancia y digestibilidad de la fibra detergente neutro, se consideran de buena calidad(12).

Uno de los criterios importantes en la selección de alguna variedad de avena es la composición de la biomasa; se ha reportado que la cantidad de las partes que la conforman, tallo, inflorescencia y hoja, están muy ligadas a la calidad nutritiva del forraje y además tienen mayor preferencia de consumo por el animal(13).

Sin embargo, la producción de este cultivo está muy influenciada por la interacción genotipoambiente; en los Valles Altos se han encontrado diferencias en materia seca de hasta 10 ha-1 $^{-1}$ entre regiones y de 1.7 a $3.7 \mathrm{t} \mathrm{ha}^{-1}$ entre variedades(14). Actualmente se desconocen las variedades y las características forrajeras, que puedan ser una alternativa para incrementar la productividad pecuaria con los mismos recursos del sistema de producción en estas áreas. Por tanto, el objetivo del estudio fue determinar producción de materia seca, calidad nutricional del forraje, así como los componentes de rendimiento de seis variedades de avena en condiciones de temporal en Zacatecas.

\section{MATERIALES Y MÉTODOS}

Los experimentos se llevaron a cabo en condiciones de temporal durante los años 2011 y 2012, en un rancho del municipio de Monte Escobedo, Zacatecas, situado al suroeste del estado a 103을 31' O y 22ㅇ 14' N, a 2,190 msnm. El suelo es un Feozem con pH de 4.8; el clima es semiárido templado y la concentración de lluvias es en verano-otoño. El promedio (de 42 años de 1961 a 2003) de la precipitación anual durante el ciclo de cultivo es de $606 \mathrm{~mm}$. En los años de evaluación la precipitación estuvo debajo de la media histórica, únicamente se acumuló el 33.9 \% (206 mm) y el $71.1 \%$ (437 $\mathrm{mm}$ ) del promedio en el 2011 y 2012, respectivamente. En la Figura 1 se presenta la distribución mensual de la precipitación acumulada, así como las temperaturas máximas been reported that the stem, inflorescence and leaf, are closely linked to the nutritive forage quality and have also greater preference of consumption by the animal(13).

However, the production of this crop is highly influenced by the genotype-environment interaction; in the High Valleys have been found

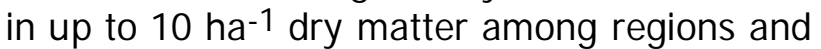
differences of 1.7 to $3.7 \mathrm{t}$ ha-1 among varieties(14). Currently, varieties and forage characteristics, which can be an alternative to increase livestock productivity with the resources of the production systems in these areas, are unknown. Therefore, the objective of the study was to determine dry matter production, forage nutritional quality, as well as yield components of six oats varieties under rainfed conditions in Zacatecas.

\section{MATERIALS AND METHODS}

The experiments were conducted under rainfed conditions during the years 2011 and 2012, on a ranch in the municipality of Monte Escobedo, Zacatecas, located to the Southwest of the State at $103^{\circ} 31^{\prime} \mathrm{W}$ and $2214^{\prime} \mathrm{N}$, and 2,190 $\mathrm{m}$ asl. The soil is a Feozem, $\mathrm{pH} 4.8$; the climate is semi-arid temperate and the concentration of rainfall in summer-autumn. Average ( $42 \mathrm{yr}$ from 1961 to 2003) of annual precipitation during the harvest cycle was $606 \mathrm{~mm}$. In the years of the experiment, the rainfall was below the historical average, only accumulated the $33.9 \%$ $(206 \mathrm{~mm})$ and the $71.1 \%(437 \mathrm{~mm})$ of the average in 2011 and 2012, respectively. Figure 1 presents the monthly distribution of accumulated rainfall, as well as the maximum and minimum temperatures for both years compared with the historical average.

Planting was carried out manually. Varieties used were, Karma, Agata, Obsidiana, Turquesa and Saia; the control variety was Chihuahua, being the best-known in the region. Planting density was $120 \mathrm{~kg} \mathrm{ha}-1$. Sowing dates were on July 29, 2011 and July 27, 2012. Chemical fertilization, applied at the time of sowing, was 
y mínimas de los dos años de evaluación comparadas con las medias históricas.

En los dos años de estudio la siembra se realizó manualmente a tierra venida. Las variedades que se utilizaron fueron, Karma, Agata, Obsidiana, Turquesa y Saia, la variedad testigo fue Chihuahua, por ser la más conocida en la región. La densidad de siembra fue de $120 \mathrm{~kg}$ ha $^{-1}$. Las fechas de siembra fueron el 29 de julio del 2011 y el 27 de julio del 2012. La fertilización química, la cual se aplicó al momento de la siembra, fue de $60 \mathrm{~kg}$ de $\mathrm{N}$ utilizando urea y $40 \mathrm{~kg}$ de $\mathrm{P}_{2} \mathrm{O}_{5}$ mediante el producto comercial 18-46-00.

El diseño experimental fue bloques completos al azar con tres repeticiones. La unidad experimental fue de siete surcos de $0.29 \mathrm{~m}$ de ancho por $6.0 \mathrm{~m}$ de largo, en la parcela útil se utilizaron los cinco surcos centrales con $5.0 \mathrm{~m}$ de largo; el área total fue de $7.25 \mathrm{~m}^{2}$. La cosecha de las plantas se realizó manualmente en el estado fenológico de lechoso-masoso.

En cada parcela se estimó la producción de forraje verde, posteriormente, se obtuvo una muestra de $0.5 \mathrm{~kg}$ y se llevó a una estufa a 60 ${ }^{\circ} \mathrm{C}$ hasta llegar a peso constante, con estos datos se determinó el porcentaje de materia seca. El rendimiento de materia seca por hectárea se calculó a partir de la producción de forraje verde de las parcelas y el porcentaje de materia seca de las muestras. De una muestra tomada al azar de cada parcela se separaron las partes vegetativas de la planta: tallo, hoja y espiga, enseguida se secaron por separado en la estufa (a $60{ }^{\circ} \mathrm{C}$ ) hasta que llegaron a peso constante; para calcular el porcentaje de tallo, hoja y espiga, cada una se dividió con el peso total de la biomasa. Las variables medidas fueron: rendimiento de forraje seco, altura de planta, días de siembra a cosecha, porcentaje del peso de hoja, de tallo y espiga.

Las muestras de forraje con las que se determinaron los porcentajes de materia seca fueron procesadas en un molino Willy con criba
Figura 1. Precipitación mensual $(\mathrm{mm})$ y temperaturas $\left({ }^{\circ} \mathrm{C}\right.$, máximas y mínimas) de Monte Escobedo, Zacatecas en los años 2011 y 2012

Figure 1. Monthly rainfall $(\mathrm{mm})$ and temperatures $\left({ }^{\circ} \mathrm{C}\right.$, maximum and minimum) of Monte Escobedo, Zacatecas. 2011 and 2012

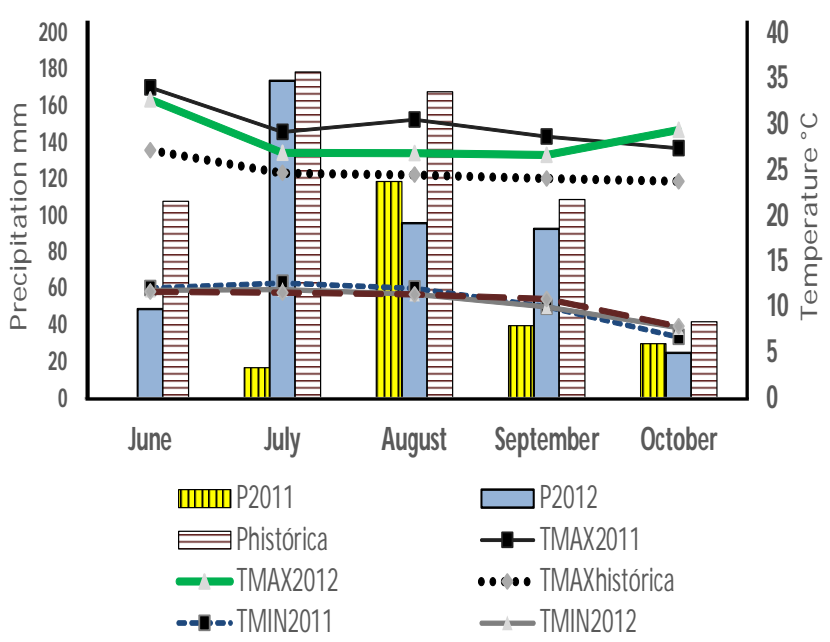

$60 \mathrm{~kg} \mathrm{~N}$ through urea and $40 \mathrm{~kg}$ of $\mathrm{P}_{2} \mathrm{O}_{5}$ by the commercial product 18-46-00.

The experimental design was a random complete blocks with three replications. The experimental unit was seven rows of $0.29 \mathrm{~m}$ wide by $6.0 \mathrm{~m}$ long, and the useful plot were the five central rows $5.0 \mathrm{~m}$ long; the total area was $7.25 \mathrm{~m}^{2}$. Harvesting was carried out manually in the milky-dough phenological state.

In each plot fresh forage production was estimated, and then a sample of $0.5 \mathrm{~kg}$ was obtained and led to an oven at $60{ }^{\circ} \mathrm{C}$ until constant weight; with these data, the percentage of dry matter was determined. The dry matter yield per hectare was calculated from fresh forage plots production and the percentage of dry matter of the samples. From a sample taken at random from each plot, the vegetative parts of the plant were separated: stem, leaf and spike, then dried separately on the stove (at $60^{\circ} \mathrm{C}$ ) until reaching constant weight; to calculate the stem, leaf and spike percentage, each was divided by the total biomass weight. 
de un milímetro. A todas las muestras se les determinó el porcentaje de proteína cruda (PC) mediante el método de Dumas por combustión AOAC(15) utilizando el equipo LECO. El contenido de fibra detergente neutro (FDN) y fibra detergente ácida (FDA) se determinaron con la técnica de detergentes (16) usando un analizador de fibra ANKOM. Para el porcentaje de materia orgánica (MO), se tomó $1.0 \mathrm{~g}$ de muestra y se colocó en crisoles, después se metió en una mufla a $550{ }^{\circ} \mathrm{C}$ durante seis horas, se pesaron las cenizas y por diferencia se obtuvo el porcentaje de MO. Las variables total de nutrientes digestibles (TDN), digestibilidad de la materia seca (DigMS), ingestión de la materia seca (IngMS), valor alimenticio relativo (VRA) y energía neta para lactación (ENL) se calcularon utilizando las ecuaciones adaptadas por Horroks y Vallentine(17). El análisis estadístico consistió en un análisis de varianza combinado entre años y se separaron las medias utilizando el paquete estadístico SAS(18). También se realizó un análisis de correlación entre las variables, eligiendo aquéllas que fueron significativas al $5 \%$.

\section{RESULTADOS Y DISCUSIÓN}

Las medias de las variables agronómicas evaluadas se muestran en el Cuadro 1. En las variables altura de planta y producción de materia seca, el análisis de varianza combinado presentó diferencias en efecto de años y variedad $(P<0.05)$, y no hubo interacción año*variedad. En la comparación de medias de las variedades se encontraron diferencias en altura de planta y producción de materia seca, Saia fue la que presentó los valores más altos $(\mathrm{P}<0.05)$ superando al testigo, cuyo resultado fue similar a las demás $(P>0.05)$. En días de siembra a cosecha (dds), Saia se caracterizó por tener el ciclo más largo con 106 días. En el segundo año, los cultivares reflejaron mayor rendimiento debido a que fue mayor el volumen de la precipitación y su distribución fue más uniforme que en 2011.

Los rendimientos de forraje seco que se obtuvieron con la variedad testigo son similares
Variables measured were: dry matter yield, plant height, days from sowing to harvest, percentage of the weight of leaf, stem, and spike.

Samples of forage for determining the dry matter percentages were processed in a Willy mill with a one millimeter sieve. In all samples the percentage of crude protein (CP) was determined by the Dumas combustion AOAC method(15) using the LECO equipment. Neutral detergent fiber content (NDF) and acid detergent fiber (ADF) were determined with the detergents technique(16) using a fiber ANKOM analyzer. For the percentage of organic matter (OM), a sample of $1.0 \mathrm{~g}$ was placed in a crucible, then got into a flask to $550{ }^{\circ} \mathrm{C}$ for $6 \mathrm{~h}$, weighed the ashes and the OM percentage was obtained by difference. The variables total digestible nutrients (TDN), dry matter digestibility (DMD), dry matter intake (DMI), relative nutritional value (RNV) and net energy for lactation (NEL) were calculated using the equations adapted by Horroks and Vallentine(17). Statistical analysis consisted of an analysis of variance combined across years and means were separated using the SAS statistical package(18); and also an analysis of correlation among variables, choosing those that were significant at $5 \%$.

\section{RESULTS AND DISCUSSION}

The averages of agronomic variables evaluated are shown in Table 1. In plant height and dried matter yield variables, the combined analysis of variance showed differences by effect of years and variety $(P<0.05)$, but not year*variety interaction. In the means comparison of the varieties there were differences in plant height and dry matter yield, Saia presented the highest values $(P<0.05)$ against the control, whose result was similar to the others $(P>0.05)$. In days from sowing to harvest, Saia was characterized by having the longest cycle with $106 \mathrm{~d}$. In the second year, cultivars reflected better performance since the rainfall was higher and its distribution was more uniform than in 2011. 
Cuadro 1. Altura de planta, rendimiento de forraje y días de siembra a cosecha de variedades de avena evaluadas en Monte Escobedo, Zacatecas

Table 1. Plant height, forage yield and days from sowing to harvest from oats varieties evaluated in Monte Escobedo, Zacatecas

\begin{tabular}{lccccccccc}
\hline & \multicolumn{1}{c}{ Varieties } \\
\cline { 2 - 9 } & Chihuahua & Karma & Obsidiana & Turquesa & Agata & Saia & \multicolumn{1}{c}{ CV } & $\mathrm{r}^{2}$ \\
\hline Plant height, $\mathrm{cm}$ & $96.4 \mathrm{~b}$ & $95.5 \mathrm{~b}$ & $98.5 \mathrm{~b}$ & $94.8 \mathrm{~b}$ & $96.0 \mathrm{~b}$ & $121.1 \mathrm{a}$ & 2.99 & 0.91 \\
Forage yield, kg & $2886.7 \mathrm{~b}$ & $2727.9 \mathrm{~b}$ & $2881.1 \mathrm{~b}$ & $2712.6 \mathrm{~b}$ & $2953.1 \mathrm{~b}$ & $4763.7 \mathrm{a}$ & 21.0 & 0.76 \\
Days sowing-harvest & 86 & 86 & 86 & 86 & 86 & 106 & & \\
\hline
\end{tabular}

$\mathrm{CV}=$ Coefficient of variation.

ab Values with different superscript differ $(P<0.05)$.

a los documentados para el potencial productivo de avena de temporal en Zacatecas, de 1 a $3 \mathrm{t}$ ha-1(2); sin embargo, son menores a los observados con Saia. En general estos rendimientos son inferiores a los encontrados en dos localidades de Jalisco donde se utilizaron las mismas variedades con manejo agronómico y ambientes climáticos similares a los de este estudio, donde González et al(19) reportaron rendimientos de 5.1 a $6.1 \mathrm{t} \mathrm{ha}^{-1}$ y Villarreal et al(20) de 4.1 a 8.5 t. Los bajos rendimientos de materia seca se pudieran atribuir al pH del suelo, reportado de 4.8 para este estudio, ya que el óptimo para avena está en el rango de 5.5 a 7.0(3). Se han reportado que existen variedades que logran tolerar $\mathrm{pH}$ menores a 4.5(21) pero su potencial de rendimiento disminuye. Las diferencias encontradas entre las variedades pueden atribuirse a sus características agronómicas; se ha demostrado que en especies forrajeras, la altura de planta y los días de siembra a cosecha están relacionados con el contenido de biomasa $(7,22)$.

La variedad Saia es una buena alternativa para incrementar la materia seca por hectárea, incluso puede alimentar más unidades animal en comparación al testigo. Sería recomendable realizar prácticas para incrementar el pH de los suelos; logrando lo anterior y con precipitaciones acumuladas parecidas a la media histórica, las producciones de forraje pudieran ser similares a los lugares de ambientes intermedios para
Yields of dry forage in the control variety were similar to those documented for the productive potential of oats in Zacatecas under rainfed conditions, from 1 to $3 \mathrm{t} \mathrm{ha}{ }^{-1(2)}$; however, they are smaller than those observed with Saia. These yields are generally lower than those found in two localities of J alisco with the same varieties and similar agronomical management and climatic environments, where Gonzalez et al(19) reported yields of 5.1 to $6.1 \mathrm{t} \mathrm{ha}^{-1}$ and Villarreal et al(20) of 4.1 to $8.5 \mathrm{t}$. Low dry matter yields could be the result of the $4.8 \mathrm{pH}$ soil reported for this study, while the optimum for oats is in the range of 5.5 to 7.0 (3). There are varieties that tolerate $\mathrm{pH}$ lower than 4.5 , but decreases its yield potential(21). Differences among varieties are attributable to their agronomic characteristics. It has shown that in forage species, plant height and days from sowing to harvest are related to the biomass content(7.22).

The Saia is a good alternative for increasing the dry matter per hectare, and even this variety can feed more animal units than the control. It would be advisable to carry out practices to increase the soils $\mathrm{pH}$; by making this and similar accumulated rainfall to the historical average, the forage yields could be similar to the areas of intermediate environments for oats in Mexico, with a reported yield of $8.4 \mathrm{t}^{\mathrm{a}} \mathrm{-1}(23)$.

The varieties yield components are shown in Figure 2. The combined analysis of variance 
PRODUCCIÓN DE FORRAJE DE VARIEDADES DE AVENA EN CONDICIONES DE TEMPORAL

avena en México, con rendimientos reportados de 8.4 t ha-1(23).

Los componentes de rendimiento de las variedades se muestran en la Figura 2. El análisis de varianza combinado mostró diferencias en los factores de variación; para el factor año, solamente hoja presentó diferencias $(P<0.001)$; en el factor variedad y la interacción año y variedad, los tres componentes presentaron diferencias $(P<0.05)$. En la comparación de las medias, Saia sobresalió $(P<0.05)$ de todas las variedades con porcentajes mayores de hoja $(24.2 \%)$ y tallo $(56.4 \%)$, mientras que Karma presentó los menores porcentajes de tallo con un $35.4 \%$ y el mayor contenido de espiga, $46.1 \% \quad(P<0.05)$ : estos resultados fueron estadísticamente diferentes al testigo.

El conocimiento de la composición de la biomasa de estas variedades es importante, ya que Assefa y Ledin(24) mencionan que se pudieran seleccionar algunas de ellas para diferentes usos, como la utilización en pastoreo, la conservación en heno o ensilaje y como doble propósito para grano-forraje. López y Kellaway(25) encontraron que la mayor digestibilidad de la materia seca de los componentes de esta especie se encuentra en las hojas y espigas, en tallo es menor debido a que la cantidad de lignina es más alta. También se menciona(26) que el consumo de la planta por animales está relacionado con especies de mayor acumulación de hoja, que con tallos, incluso si estas dos tienen digestibilidades similares. Por las proporciones de hoja y tallo que presentó la variedad Saia se recomienda su uso en henificado o ensilado, mientras que Karma y el testigo podrían ser para doble propósito (granoforraje) debido al porcentaje de espiga que acumularon.

Las medias de las variables nutricionales se observan en el Cuadro 2. El análisis de varianza combinado no mostró diferencias ( $P>0.05)$ entre los factores de variación de PC. En MO solamente se observó diferencia en años $(P<0.05)$. Para FDA, TDN, DigMS, VRF Y ENL se presenta únicamente en variedades $(P<0.05)$.
Figura 2. Proporción de los componentes de rendimiento de las variedades de avena

Figure 2. Proportion of yield components of oats varieties

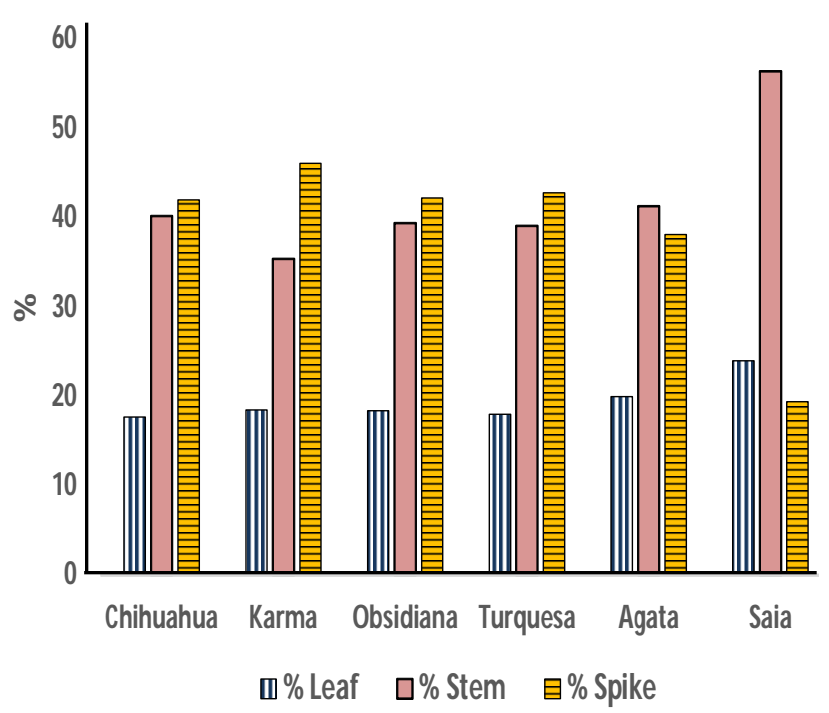

showed differences in the factors of variation: for the year factor, only leaf presented differences $(P<0.001)$, in variety factor and interaction year*variety, the three components showed differences $(P<0.05)$. In the means comparison, Saia excelled $(P<0.05)$ all varieties with higher leaf percentage $(24.2 \%)$ and stem (56.4 \%), while Karma presented the lower percentage of stem with a $35.4 \%$ and the highest content of spike, $46.1 \% \quad(P<0.05)$ : these results were statistically different from the control.

Knowledge of the biomass composition of these varieties is important, since Assefa and Ledin(24) mentioned that some of them might be selected for different uses, as for grazing, hay or silage storage and dual purpose grain-forage. Lopez and Kellaway(25) found that higher dry matter digestibility of the components of this species is in the leaves and spikes; in stem is smaller because the amount of lignin is higher. Others mentioned(26) that the consumption of the plant by animals is related to species of greater accumulation of leaf than the stem, even if these two have similar digestibility. By the ratios of leaf and stem presented, the Saia variety is 
En FDN y PC, se observó en año y variedad $(P<0.05)$, pero no en la interacción ente ellos. En la comparación de medias de las variedades los valores de PC y MO fueron similares entre los cultivares con escalas de 113 a $132 \mathrm{~g} / \mathrm{kg}$ y 887 a $914 \mathrm{~g} / \mathrm{kg}$, respectivamente. En las variables restantes se presentaron diferencias estadísticas. En FDN, Ágata acumuló el más alto porcentaje con $61 \%$, y Karma fue la de menor concentración con $51.3 \%$, siendo estas dos diferentes al testigo $(P<0.05)$. En FDA Karma mostró resultados con $349 \mathrm{~g} / \mathrm{kg}$ y fue inferior al testigo $(P<0.05)$, en los demás cultivares la acumulación fue mayor a $395 \mathrm{~g} / \mathrm{kg}$. En PC Saia sobresale $(P<0.05)$ con $544.2 \mathrm{~kg} \mathrm{ha}^{-1}$. En TDN, DigMS, VRF y ENL, Karma superó a todas las variedades $(P<0.05)$ con $56.4 \%, 61.7 \%, 111.8$ y $1.38 \mathrm{Mcal} \mathrm{kg}^{-1}$, respectivamente. Estos resultados coinciden a los reportados en otros estudios donde determinaron la composición bromatológica del forraje de avenas en estado lechoso-masoso $(27,28,29)$.

De acuerdo con las características proteicas y energéticas, los resultados del forraje de estas variedades se consideran con calidad nutritiva de baja a regular para PC y de regular a buena para Enl(12). Kraiem et al(27) evaluaron la recommended by hen or silage use, while Karma and the control could be dual purpose (grainforage) due to the percentage of spike accumulated.

The means of the nutritional variables are seen in Table 2. The combined analysis of variance showed no differences ( $P>0.05)$ among the factors of variation for $C P$. Difference in years was only observed in OM $(P<0.05)$. For FDA, TDN, DMD, RNV and NEL occurs only in varieties $(P<0.05)$. In NDF and $C P$, was observed in year and variety $(P<0.05)$, but not in its interaction. In the means variety comparisons, the values of $\mathrm{CP}$ and $\mathrm{OM}$ were similar among cultivars with ranges of 113 to $132 \mathrm{~g} / \mathrm{kg}$ and 887 to 914 $\mathrm{g} / \mathrm{kg}$, respectively. Statistical differences were found in the remaining variables. For NDF, Agata accumulated the highest percentage with $61 \%$, and Karma the lowest with $51.3 \%$, being these two different than the control $(P<0.05)$. In FDA, Karma showed results of $349 \mathrm{~g} / \mathrm{kg}$ and was lower than the control $(P<0.05)$, in other cultivars accumulation was greater at $395 \mathrm{~g} / \mathrm{kg}$. For $C P$, Saia stands $(P<0.05)$ with $544.2 \mathrm{~kg}$ ha-1. In TDN, DMD, RNV, and NEL, Karma surpassed all varieties $(P<0.05)$ with 56.4 , $61.7 \%, 111.8$, and $1.38 \mathrm{Mcal}^{\mathrm{kg}}{ }^{-1}$, respectively.

Cuadro 2. Características nutricionales de las variedades de avena evaluadas en Monte Escobedo, Zacatecas.

Table 2. Chemical characteristics of oat varieties evaluated in Monte Escobedo, Zacatecas

\begin{tabular}{lccccccccc}
\hline & CP & OM & NDF & ADF & CP $(\mathrm{kg} / \mathrm{ha})$ & TDN & DMD & RFV & NEL \\
\cline { 2 - 9 } Varieties & $(\mathrm{g} / \mathrm{kg})$ & $(\mathrm{g} / \mathrm{kg})$ & $(\mathrm{g} / \mathrm{kg})$ & $(\mathrm{g} / \mathrm{kg})$ & & $(\%)$ & $(\%)$ & & $(\mathrm{Mcal} \mathrm{kg})$ \\
\hline Chihuahua & 113 & 890 & $564 \mathrm{~b}$ & $405 \mathrm{a}$ & $331.3 \mathrm{~b}$ & $49.1 \mathrm{~b}$ & $57.3 \mathrm{~b}$ & $94.7 \mathrm{bc}$ & $1.23 \mathrm{~b}$ \\
Karma & 114 & 914 & $513 \mathrm{C}$ & $349 \mathrm{~b}$ & $332.9 \mathrm{~b}$ & $56.4 \mathrm{a}$ & $61.7 \mathrm{a}$ & $111.8 \mathrm{a}$ & $1.38 \mathrm{a}$ \\
Obsidiana & 122 & 893 & $563 \mathrm{~b}$ & $395 \mathrm{a}$ & $315.4 \mathrm{~b}$ & $50.3 \mathrm{~b}$ & $58.1 \mathrm{~b}$ & $98.1 \mathrm{~b}$ & $1.26 \mathrm{~b}$ \\
Turquesa & 114 & 906 & $569 \mathrm{~b}$ & $401 \mathrm{a}$ & $329.5 \mathrm{~b}$ & $49.6 \mathrm{~b}$ & $56.7 \mathrm{~b}$ & $95.4 \mathrm{~b}$ & $1.24 \mathrm{~b}$ \\
Agata & 132 & 887 & $611 \mathrm{a}$ & $427 \mathrm{a}$ & $385.3 \mathrm{~b}$ & $46.2 \mathrm{~b}$ & $55.6 \mathrm{~b}$ & $85 \mathrm{c}$ & $1.17 \mathrm{~b}$ \\
Saia & 117 & 895 & $603 \mathrm{ab}$ & $419 \mathrm{a}$ & $544.2 \mathrm{a}$ & $47.2 \mathrm{~b}$ & $56.2 \mathrm{~b}$ & $87 \mathrm{bc}$ & $1.19 \mathrm{~b}$ \\
CV & 5.7 & 2.4 & 4.1 & 4.3 & 24.6 & 4.8 & 2.6 & 9.8 & 6.1 \\
$\mathrm{r}^{2}$ & 0.57 & 0.72 & 0.72 & 0.68 & 0.71 & 0.68 & 0.67 & 0.71 & 0.67 \\
\hline
\end{tabular}

$\mathrm{CP}=$ Crude protein; $\mathrm{OM}=$ Organic matter; $\mathrm{NDF}=$ Neutral detergent fiber; $\mathrm{ADF}=$ Acid detergent fiber; TDN= Total digestible nutrients; $\mathrm{DMD}=$ Dry matter digestibility; $\mathrm{RFV}=$ Relative forage value; $\mathrm{NEL}=\mathrm{Net}$ energy for lactation; $\mathrm{CV}=\mathrm{Coefficient}$ of variation.

ab Values in columns with different superscript differ $(P<0.05)$. 
PRODUCCIÓN DE FORRAJE DE VARIEDADES DE AVENA EN CONDICIONES DE TEMPORAL

composición química y la digestibilidad del forraje de avena en tres estados fenológicos: lechoso, masoso y grano duro, encontrando contenidos de $35.5,37.7$ y $40.1 \%$ de FDA y $62.7,64.5$ y $67.6 \%$ de FDN, respectivamente. El autor concluyó que la diferencia entre los estados fenológicos fue numérica, pero no estadísticamente significativa. Wallsten et al(30) mencionan que un incremento de FDN en el forraje afecta negativamente el consumo de la materia seca.

Algunos autores $(31,32)$ utilizan las variables TDN y VRF como indicadores para evaluar la calidad de henos de leguminosas o gramíneas, o para la asignación de forraje a grupos de animales de acuerdo a los requerimientos nutricionales. Para los requerimientos del ganado productor de leche y los valores obtenidos de las variedades en este estudio, se cubrirían los requerimientos de becerras de 12 a 24 meses y también de vacas $\operatorname{secas}(33)$.

En el presente estudio se podría asumir que Karma tendría mejor productividad animal debido a los bajos contenidos de fibra y a los altos valores forrajeros que presentó. Por otro lado, los kilogramos de PC que obtuvo Saia se pueden atribuir a la alta cantidad de materia seca que produjo por hectárea.

El análisis de coeficientes de correlación entre características agronómicas, morfológicas y nutricionales se presenta en el Cuadro 3. En él se observa que las variables asociadas de manera positiva con el rendimiento de forraje seco son: altura de planta $(r=0.701)$, días de siembra a cosecha $(r=0.685)$ y acumulación de tallo (0.629); negativamente se relacionó con la cantidad de espiga $(r=-0.525)$.

La relación entre características agronómicas y morfológicas para la acumulación de hoja, se asoció positivamente con días de siembra a cosecha $(r=0.448)$ y negativamente con el porcentaje de espiga ( $r=-0.727)$. También la hoja, el tallo y la espiga se asociaron de manera positiva $(P<0.05)$ con FDA y FDN; sin embargo, su porcentaje de correlación fue bajo.
These results correspond to those reported in other studies where the chemical composition of oat forage in milky-dough stage of maturity were determined $(27,28,29)$.

According to the protein and energy characteristics, the forage of these varieties are considered of low nutritive quality, regular CP and regular to good for NEL(12). Kraiem et al(27) evaluated chemical composition and digestibility of forage oats in three phenological stages: milky, dough, and hard grain, finding contents of 35.5, 37.7 and $40.1 \%$ of ADF and $62.7,64.5$ and $67.6 \%$ of NDF, respectively. The authors concluded that the difference among the phenological stages was numerical, but not statistically significant. Wallsten et al(30) mentioned that an increase of NDF in the forage adversely affects the dry matter intake.

Some authors $(31,32)$ use the TDN and RNV variables as indicators to evaluate the quality of legume hay or grass, or for the allocation of forage to groups of animals according to nutritional requirements. For the milk producer livestock and the values of the varieties obtained in this study, it would cover the requirements of 12 to $24-m o$ heifers and also for dry cows(33).

In this study, it can be assumed that Karma would have improved animal productivity due to the low fiber content and high forage values presented. On the other hand, the CP obtained by Saia can be attributed to the high amount of dry matter produced per hectare.

The correlation coefficient analysis among agronomic, morphological, and nutritional traits is presented in Table 3. It shows that the variables associated positively with dry forage yield are plant height $(r=0.701)$, days from sowing to harvest $(r=0.685)$ and stem accumulation (0.629), and it was negatively related to the amount of spike $(r=-0.525)$.

The relationship between agronomic and morphological characteristics for the accumulation of 
Cuadro 3. Coeficiente de correlación entre características agronómicas, morfológicas y nutricionales de variedades de avena evaluadas en el municipio de Monte Escobedo, Zacatecas (2011)

Table 3. Correlation coefficients among agronomic, morphologic and nutritional characteristics of oat varieties in the Municipality of Monte Escobedo, Zacatecas (2011)

\begin{tabular}{|c|c|c|c|c|c|c|c|c|c|c|c|}
\hline & DF & $\mathrm{PH}$ & DAS & Leaf & Stem & Spike & $\mathrm{CP}$ & $\mathrm{OM}$ & NDF & ADF & $\mathrm{KCP}$ \\
\hline DF & 1.000 & & & & & & & & & & \\
\hline $\mathrm{PH}$ & $0.701^{\star \star}$ & 1.0000 & & & & & & & & & \\
\hline DAS & $0.685^{\star \star}$ & $0.927^{* *}$ & 1.000 & & & & & & & & \\
\hline Leaf & 0.021 & 0.338 & $0.448^{*}$ & 1.000 & & & & & & & \\
\hline Stem & $0.629^{\star \star}$ & $0.715^{\star \star}$ & $0.806^{\star *}$ & 0.457 & 1.000 & & & & & & \\
\hline Spike & $-0.525^{\star}$ & $-0.696^{\star \star}$ & $-0.807^{\star \star}$ & $-0.727^{\star \star}$ & -0.939 ** & 1.000 & & & & & \\
\hline $\mathrm{CP}$ & 0.119 & -0.136 & -0.093 & -0.150 & 0.021 & 0.042 & 1.000 & & & & \\
\hline OM & $0.339^{*}$ & 0.152 & 0.070 & -0.123 & -0.076 & 0.075 & -0.216 & 1.000 & & & \\
\hline NDF & 0.059 & 0.205 & 0.258 & $0.561^{*}$ & $0.447^{\star}$ & $-0.527^{*}$ & 0.006 & -0.234 & 1.000 & & \\
\hline ADF & 0.186 & 0.209 & 0.243 & $0.397^{*}$ & $0.466^{*}$ & $-0.480^{*}$ & 0.039 & -0.006 & $0.887^{\star *}$ & 1.0000 & \\
\hline $\mathrm{KCP}$ & $0.934^{\star *}$ & $0.551^{*}$ & $0.547^{*}$ & 0.070 & $0.544^{*}$ & $-0.422^{*}$ & 0.453 & 0.231 & 0.003 & 0.132 & 1.000 \\
\hline
\end{tabular}

$\mathrm{DF}=$ Dry forage; $\mathrm{PH}=$ Plant height; $\mathrm{DAS}=$ Days after sowing; $\mathrm{CP}=$ Crude protein; $\mathrm{OM}=$ Organic matter; $\mathrm{NDF}=$ Neutral detergent fiber; $A D F=$ Acid detergent fiber; $K C P=$ Kilograms of crude protein. ${ }^{*}(P<0.05) ;{ }^{* \star}(P<0.001)$.

El tallo tuvo relaciones positivas $(\mathrm{P}<0.001)$ con altura de planta, forraje seco y días de siembra a cosecha. En espiga se obtuvieron resultados similares pero su relación fue negativa $(P<0.05)$. En los kilogramos de proteína cruda la relación que se observó fue únicamente con las variables que se asocian con la producción de forraje seco.

Estos resultados muestran que las variedades más precoces tienden a ser de porte bajo, con menor producción de materia seca, poca hoja y tallo pero debido a que la acumulación de espiga es alta, tienen potencial para la producción de grano. Villareal et al(19) no encontraron diferencias en el rendimiento de forraje de estas variedades, aunque se observan materiales precoces y tardíos. En otras investigaciones indican que variedades de avena con menos días a cosecha tuvieron menor rendimiento comparado con materiales tardíos y de porte alto(34).

\section{CONCLUSIONES E IMPLICACIONES}

En la calidad nutritiva del forraje, los porcentajes de proteína cruda fueron similares entre las leaf, was positively associated with days of planting to harvest $(r=0.448)$ and negatively with the percentage of spike $(r=-0.727)$. Also the leaf, stem and spike were associated positively $(P<0.05)$ with ADF and NDF; however, its correlation percentage was low.

The stem had positive relationships $(P<0.001)$ with plant height, dry forage, and days from sowing to harvest. Similar results were obtained with the spike, but their relationship was negative $(P<0.05)$. In kilograms of crude protein, the relationship observed was only with variables that are associated with dry forage production.

These results show that the most precocious varieties tend to be smaller, with reduced dry matter production, little leaf and stem, but because the accumulation of spike is high, they have potential for grain production. Villarreal et al(19) found no differences in the yield of these varieties, although there are early and late materials. In other investigations indicate that oats varieties with fewer days to harvest had reduced yields relative to high late materials(34). 
variedades. La variedad Karma fue inferior a las demás en la acumulación de fibras, por lo que presentó el mejor valor forrajero en los dos años. La variedad Saia fue la más tardía y debido al mayor contenido de hoja que mostró así como el rendimiento de forraje seco que produce, se propone como una buena alternativa para solucionar los problemas de bajos rendimientos de materia seca por hectárea.

\section{LITERATURA CITADA}

1. Servicio de información Agroalimentaria y Pesquera (SIAP). Anuario estadístico de la producción agrícola. 2011.

2. Medina GG, Salinas GH, Rubio AF. Potencial productivo de especies forrajeras en el estado de Zacatecas. 1er ed. Zacatecas México. 2001:58-59.

3. Ruiz CJ, Medina GG, González Al, Ortíz TC, Flores LH, Martínez PR, et al. Requerimientos agroecológicos de cultivos. ler ed. Jalisco México: Editorial Conexión Gráfica; 1999.

4. Nawaz N, Razzaq A, Ali Z, Sarwar G, Yousaf M. Performance of different Oat (Avena sativa L.) varieties under the agroclimatic condition of Bahawalpur-Pakistan. Int J Agri Biol 2004;6(4):624-626.

5. Weichenthal BA, Baltensperger DD, Vogel KP, Masterson SD, Krall JM. Case study: Nutrients values of spring and summer annual forages in a single cut harvest. The Prof Anim Sci 2008; (24):668-674.

6. Coblentz WK, Walgenbach RP. Fall growth, nutritive value, and estimation of total digestible nutrients for cereal-grain forages in the north-central United States. J Anim Sci 2010; (88): 383-399.

7. Fisher LJ, Flower DB. Predicted forage value of whole plant cereals. Can J Plant Sci 1975;(55):975-986.

8. Hadjipanayiotou M, Antoniou I, Theodoridou M, Photiou A. In situ degradability of forage cut at different stages of growth. Liv Prod Sci 1996; (45):49-53.

9. Mayer HJ, Weir WC, Jones LG, Hull JL. The influence of stage of maturity on the feeding-value of oat hay. J Anim Sci 1957; (16):623-632.

10. Francia E, Pecchioni N, Li Destri Nicosia O, Paoletta G, Taibi $\mathrm{L}$, Franco $\mathrm{V}$, et al. Dual-purpose barley and oat in a Mediterranean environment. Field Crop Res 2006; (99):158166.

11. Feyissa F, Tolera A, Melaku S. Effects of variety and growth stage on proportion of different morphological fractions in oats (Avena sativa L.). Degefa T, Feyyissa F editors. Proc 15th Ann Conf Ethiopian Soc Anim Prod (ESAP) Ethiopia 2007:47-61

12. Núñez HG, Payán G , Peña RA, González CF, Ruiz BO, Arzola AC. Caracterización agronómica y nutricional del forraje de variedades de especies anuales en la región norte de México. Téc Pecu Méx 2010;1(2):85-98.

\section{CONCLUSIONS AND IMPLICATIONS}

In the nutritive quality of forage, crude protein percentages were similar among varieties. The Karma variety was lower than the others in fiber accumulation, so it presented the best forage value in two years. The Saia variety was more delayed and due to the higher leaf content as well as the dry forage that produces, it is proposed as a good alternative to solve the problems of low dry matter yield per hectare.

\section{End of english version}

13. Folkins LP, Kaufman ML. Yield and morphological studies with oats for forage and grain production. Can J Plant Sci 1974; (54):617-620.

14. Espitia RE, Villaseñor ME, Tovar GR, de la O OM, Limón OA. Momento óptimo de corte para rendimiento y calidad de variedades de avena forrajera. Rev Méx Cienc Agr 2012;3(4): 771-783.

15. AOAC. Ofûcial Methods of Analysis. 16th ed. Assoc. Off Anal Chem, Arlington, VA. 1996.

16. Georing HK, Van Soest PJ. Forage Fiber Analysis; Apparatus Reagents, Procedures, and Some Applications. Agric 1970. Handbook 379.

17. Horrocks RD. Vallentine JF. Harvested forage. London, UK: Academic Press; 1999.

18. SAS. User Guide. Statistical Analysis System. Inc. Cary, NC. versión 9.1. 2002.

19. González A, Arias LE, Yáñez A, González LA, Silva M, Vega MA. et al. Producción y calidad de forraje de siete variedades de avena en diferentes etapas de corte en el sur de Jalisco. En: Flores NM, Reveles TL, et al editores. Reunión Internacional Conjunta de Manejo de Pastizales y Producción Animal. Zacatecas, México 2012:131-135.

20. Villareal JH, Arias LE, Sánchez RA, Tovar MR, Núñez HG. Caracterización agronómica y nutricional del forraje de cereales de grano pequeño en los altos de Jalisco. En: Castellanos PE, Serrato CS, et al editores. Semana Internacional de Agronomía. Durango, México 2012:13971401.

21. Valenzuela H. Smith J. Common oats. Sustainable agriculture, green manure crops. SA-GM-5. University of Hawaii at Manoa, Honolulu, 2002. [on line] http:// www2.ctahr.hawaii.edu. Accessed Feb 8, 2013.

22. Navarro GH, Pérez OM, Castillo GF. Evaluación de cinco especies vegetales como cultivos de cobertura en valles altos de México. Rev Fitotec Méx 2007;30(2):151-157.

23. Espitia RE, Villaseñor MH, Huerta EJ, Osorio AL. Obsidiana: Nueva variedad de avena para la producción de grano y forraje. Campo Experimental Valle de México. CIRCE. I NIFAP. Folleto técnico No. 28. 2008. 
24. Assefa G, Ledin I. Effect of variety, soil type and fertilizer on the establishment, growth, forage yield, quality and voluntary intake by cattle of oats and vetches cultivated in pure stands and mixtures. Anim Feed Sci Tech 2001;(92):95-111.

25. Lopez TL, Kellaway R. Botanical composition and extent of lignification affecting digestibility of wheat and oat straw and paspalum hay. Anim Feed Sci Tech 1982; (7):71-81.

26. Cherney DJ, Martens DR, Moore JE. Intake and digestibility by wethers as influenced by forage morphology at three levels of forage offering. J Anim Sci 1990;(68):4387-4399.

27. Mayer JH, Weir WC, Jones LC, Hull JL. The influence of stage of maturity on the feeding-value of oat hay. J Anim Sci 1957; (16): 623-632.

28. Kraiem K, Majdoub A, Ben Abbes SW. Moujahed N. Effect of the level of supplementation with concentrate on the nutritive value and utilization of oats hay cut at three maturity stages. Liv Prod Sci 1997;(47):175-184.

29. Fulkerson WJ, Horadagona H, Neal JS, Barchia I, Nandra KS. Nutritive value of forage species grown in the warm temperate climate of Australia for dairy cows: Herbs and grain crops. Liv Sci 2008;(114):75-83.
30. Wallsten J, Nadeau E, Bertilsson J, Martinsoon K. Voluntary intake and diet selection by dairy heifers fed ensiled wholecrop barley and oats harvested at different stages of maturity. Livestock Sci 2009;(122):94-98.

31. Carr PM, Horsley RD, Poland WW. Barley, oat and cereal pea mixtures as dryland forages in the northern plains. Agron J 2004; (96):677-684.

32. Strydhorts SM, King JR, Lopetinsky KJ, Harker KN. Forage potential of intercropping barley with faba bean, Lupin, or feal Pea. Agron J 2008; (100): 182-190.

33. Jeranyama $P$, Garcia $A D$. Understanding relative feed value (RFV) and relative forage quality (RFQ). Collage of agriculture and biological science / South Dakota State University/ USD. ExEx8149, 2004. [on line] http:// agbiopubs.sdstate. edu/articles/ExEx8149.pdf. Accessed May 15, 2013.

34. Assefa G, Feyissa F, Gebeyehu A, Minta M. Characterization of selected oats varieties for the important production traits in the highlands of Ethipia. In: Yimegnuhal A, Degefa T editors. Proc $11^{\text {th }}$ Ann Conf Ethiopian Soc Anim Prod (ESAP) Ethiopia. 2003:305-314. 